\title{
PHYTOCHEMICAL AND PROXIMATE ANALYSIS OF Ipomoea cairica TUBER
}

JOHN GODSON N., ONWUGBUTA GODPOWER C., CHIMA DANIEL

(Received 13 November 2020; Revision Accepted 12 January 2021)

\begin{abstract}
The analyses for nutrients of Ipomoea cairica tuber were carried out and the phytochemical and proximate parameters were determined. The phytochemical analyses looked into the alkaloid, flavonoid, cyanogenic glycoside, tannin, phytate and saponin contents of Ipomoea cairica tuber while the proximate composition determination was aimed at the protein, carbohydrate, moisture, lipid, ash and fibre contents. The methods applied for these analytical determinations were mainly those of the Association of Official Analytical Chemist (AOAC, 2005). Each type of analysis (whether proximate or phytochemical) were carried out in triplicate and the mean values determined. The phytochemical analyses showed that Ipomoea cairica tuber had; flavonoid $(1.52 \pm 0.03 \%)$, Alkaloid $(2.10 \pm 0.28 \%)$, Tannin $(0.05 \%)$, Saponin $(1.24 \pm 0.04 \%)$, Cyanogenic glycoside $(0.05 \%)$, and phytate $(0.02 \%)$. The proximate analysis showed that Ipomoea cairica tuber had; Carbohydrate $(11.7 \pm 0.1 \%)$, protein $(4.2 \pm 0.2 \%)$, ash $(0.6 \pm 0.1 \%)$, lipid $(0.51 \pm 0.07 \%)$, moisture $(72.7 \pm 0.2 \%)$, and fibre $(10.3 \pm 0.6 \%)$. These results show that Ipomoea cairica tuber can be used as a substitute for other mostly consumed carbohydrate foods like yam and cocoyam.
\end{abstract}

KEYWORDS: Phytochemical, Proximate, Ipomoea cairica, Tuber

\section{INTRODUCTION}

The family, Convolvulaceae comprises nearly 1650 predominantly tropical species. The genus Ipomoea, with approximately $500-600$ species, comprises the largest genus of the species within the Convolvulaceae (Austin and Huáman, 1996). Ipomoea cairica has many common names, including mile-a-minute vine, messina creeper, Cairo morning glory, coast morning glory and railroad creeper (Brisbane City Council, 2007). In the western part of Nigeria, its common name is Umehuru. One of the most noticeable morphological characteristics of the Convolvulaceae is the existence of cells, which secrete resin glycosides in the foliar tissues and in the roots of the plants.
This family is dominated by twining or climbing woody or herbaceous plants that often have heart-shaped leaves and funnel-shaped flowers (Austin and Huáman, 1996). The genus Ipomoea occurs in the tropics of the world although some species also reach temperate zones (Cao et al., 2005). The species of this genus are mainly distributed throughout the South and Central America countries, and Tropical African territories (Austin and Huáman, 1996). But due to human dispersal, it occurs today on most continents as an introduced species and is sometimes a noxious weed. This plant reproduces vegetatively by rooting along its stems and also produces seeds. Stem fragments and seeds are often dispersed in dumped garden waste and can also be spread by water (Barker, 2005).

John Godson N., Department of Biochemistry/Chemistry Technology, School of Science Laboratory

Technology, University of Port Harcourt.

Onwugbuta Godpower C., Department of Biochemistry/Chemistry Technology, School of Science Laboratory Technology, University of Port Harcourt.

Chima Daniel, Department of Biochemistry/Chemistry Technology, School of Science Laboratory Technology, University of Port Harcourt. 
Some are simply weeds, whereas others are economically important, viz., sweet potatoes and still others are ornamental plants, such as the morning glories I. purpurea and I. Cairica, respectively.

The genius Ipomoea including Ipomoea cairica and Ipomoea palmate has been reported to have many biological activities. The major bioactive constituents previously isolated from the genus Ipomoea were lipoidal matters and phenolic compounds (Teow et al., 2007).

Alkaloids, phenolics compounds and glycolipids are the most common biologically active constituents from these plant extracts. (Abou-Chaar, 1997)

Several species of Ipomoea have been used as medicines. Studies have shown the potential of the genus as a source of therapeutic agents. The glycoresins within them constitute one important chemotaxonomic marker of this family (Wagner, 1993) and are responsible for the purgative properties of some species of the Convolvulaceae (Pereda-Miranda and Bah, 2003). Some of these species showed antimicrobial, analgesic, spasmolitic, spasmogenic, hypoglycemic, hypotensive, anticoagulant, antiinflammatory, psychotomimetic and anticancer activities. Plants of this genus are appropriate biological models for research, through presenting exceptional morphological and habitat-use diversity, whereby they are extensive and experimentally versatile (Stefanovi et al., 2003). Although Ipomoea cairica tuber has been consumed as food, especially during the Nigeria civil war where it was claimed to have been substituted for other tuber plants, much studies of its proximate constituent have not been carried out. (Teow, et al., 2007)

This research therefore has the following objectives.

i.To determine the proximate parameters and phytochemical properties of Ipomoea Cairica tuber ii. To determine the nutritional content of Ipomoea cairica iii. To explore the pharmaceutical application

\section{METHODS}

A large quantity of Ipomoea cairica tuber, was dug from the borrow pit opposite university of Port Harcourt main gate, around mechanic village, Choba, Port Harcourt, Rivers State, Nigeria.

The plant was identified by Mr. Jeffry of the Department of Plant Science and Biotechnology, University of Port Harcourt. The properly washed plant samples were pulverized after drying at room temperature (about $25^{\circ} \mathrm{C}$ ) for 5 weeks, oven-dried to constant weight and then defatted using Soxhlet extractor. Defatted samples were then used for further proximate analysis.

The Ipomoea cairica tuber was cleaned properly to remove sand and other unwanted particles. This sample was crushed to fine particles with the aid of a mortar and pestle and weighed. However, samples used for moisture content determination were only cleaned not grinded.

Before analysis of the sample, it was prepared using the following chemicals in different proportions: the digestion catalyst, Boric acid Indicator, Hydrochloric Acid and Methanol (80 \%). Thereafter the test sample was analysed using a UV-spectrophotometer.

$\begin{array}{lcr}\text { QUANTITATIVE } & \text { DETERMINATION } & \text { OF } \\ \text { PHYTOCHEMICAL } & \text { AND } & \text { PROXIMATE } \\ \text { CONSTITUENTS } & & \end{array}$

\section{Determination of Alkaloid}

$2.5 \mathrm{~g}$ of the sample was weighed into $250 \mathrm{ml}$ beaker and a concentration of acetic acid and ethanol in the ratio of 5:95 \% was added and allowed to stand for 4 hours. Filter in a pre-weighed Whatman No. 42 filter paper and boil, and then re-filter. After filtering, dry filter paper in an oven for about $1 \mathrm{~h}$ and allowed to cool in a desiccators. Take final weight of filter paper and record.

\section{Determination of Flavonoid}

Take $5 \mathrm{~g}$ of the sample into a beaker of about $250 \mathrm{ml}$ and add $50 \mathrm{ml}$ of $80 \%$ methanol and allowed to stay for $1 \mathrm{~h}$. Fire polish a $250 \mathrm{ml}$ volumetric flask and allow to cool and take initial weight. Filter in a whatman No. 42 filter paper and put the filtrate in a Gallikamp oven to dry. When dry, allow flask to cool and weigh flask.

\section{Determination of Cyanogenic Glycoside}

$10 \mathrm{~g}$ of crushed sample was weighed into a flask and add $20 \mathrm{ml}$ of distilled water, and allow for $24 \mathrm{~h}$ (overnight) allowing cyanide to hydrolyze if there is any. Distilled mixture in a hot plate and add ammonia as buffer. Add $1 \mathrm{ml}$ of sodium hydroxide and titrate with silver nitrate. In case of foaming, add antifoaming agent (ocatnol).

\section{Determination of Tannin}

$0.1 \mathrm{~g}$ of sample was weighed into a $250 \mathrm{ml}$ volumetric flask and $100 \mathrm{ml}$ of distilled water was added. Boil mixture until it reduces to $50 \mathrm{ml}$ and allowed to cool. Weigh $0.17 \mathrm{~g}$ of $\mathrm{Na}_{2} \mathrm{CO}_{3}$ and make it up to $10 \mathrm{ml}$ with distilled water. Pipette $1 \mathrm{ml}$ of sample into test-tube. Add $0.25 \mathrm{ml}$ of Folin Denis reagent and then make up to $5 \mathrm{ml}$ with distilled water. Allow for $30 \mathrm{~min}$ and check the absorbance at $420 \mathrm{~nm}$

\section{Determination of Phytate}

$0.1 \mathrm{~g}$ of sample was weighed into a $250 \mathrm{ml}$ volumetric flask and added $100 \mathrm{ml}$ of $0.5 \mathrm{M}$ hydrochloric acid and boil until it reduces to $50 \mathrm{ml}$. Take $10 \mathrm{ml}$ of the boiled sample and add 2 drops of phenopthtaline and neutralize with $0.5 \mathrm{M} \mathrm{NaOH}$ and the color changes to pink and make the solution slightly acidic with $0.17 \mathrm{M}$ $\mathrm{HCl}$ until mixture returns back to colorless. Make it up again to $50 \mathrm{ml}$ with distilled water and take up $10 \mathrm{ml}$ aliquot and add $4 \mathrm{ml} \mathrm{FeCl}$ into a centrifuge tube. Heat for 15 minutes at $100{ }^{\circ} \mathrm{C}$, cool and centrifuge and decant the supernatant. Add $2 \mathrm{ml}$ water to residue and heat to boiling for $5-10 \mathrm{~min}$ at $100{ }^{\circ} \mathrm{C}$ and add $2 \mathrm{ml} 0.5 \mathrm{M} \mathrm{NaOH}$ and heat again for $15 \mathrm{~min}$ and filter into conical flask. Wash the filter paper with hot water and add $0.5 \mathrm{ml}$ concentrated surphuric acid and boil until it forms white fumes. Add $3 \mathrm{ml}$ perchloric acid and $5 \mathrm{ml}$ nitric acid $\left(\mathrm{HNO}_{3}\right)$ and digest to clear solution. Dilute to $50 \mathrm{ml}$ with distilled water and analyse for phytate by ascorbic acid method. Take $5 \mathrm{ml}$ into a test tube, add $0.5 \mathrm{ml}$ of combined reagent $(3 \mathrm{ml}$ of $1.76 / 100 \mathrm{ml}$ ascorbic acid, $1.5 \mathrm{ml}$ of $4 \mathrm{~g} / 100 \mathrm{ml}$ ammonium molybdate, $0.5 \mathrm{ml}$ of 0.8 $\mathrm{g} / 100 \mathrm{ml}$ potassium antimonytartrate, and $5 \mathrm{ml}$ of 5 normal surphuric acid) and allow for $30 \mathrm{~min}$. Read optical destiny in a spectrophotometer at $520 \mathrm{~nm}$ 


\section{Determination of Saponin}

$1 \mathrm{~g}$ of grinded sample was inserted into a filter paper (thimble) and was place into a soxhlet extractor. The extractor was placed into a pre-weighed dried distillation flask. Then methanol was introduced as an extracting agent into the distillation flask via the condenser end attached to the soxhlet extractor. The set up was held in place with a retort stand clamp on the hot plate. Cooled water jet was allowed to flow into the condenser and the heated solvent was refluxed as a result. The lipid in the solvent was extracted in the process of continuous refluxing. When the lipid was observably extracted completely from the sample under test, the condenser and the extractor was disconnected and the solvent was evaporated to concentrate the lipid. The flask was then dried in the air oven to constant weight and reweighed to obtain the weight lipid.

\section{Protein Content Determination}

This analysis was carried out in three different stages which include digestion, distillation and titration.

$0.1 \mathrm{~g}$ of the sample was weighed into a clean conical flask of $250 \mathrm{ml}$ capacity, $3 \mathrm{~g}$ of digestion catalyst (10\% copper sulphate and $90 \%$ sodium sulphate) was added into the flask and $20 \mathrm{ml}$ concentrated sulphuric acid was also added and the sample was heated to digest. The content changed from black to sky-blue coloration. The digest was cooled to room temperature and was diluted to $100 \mathrm{ml}$ with distilled water.

$20 \mathrm{ml}$ of the diluted digest was measured into a flask and the flask was held in place on the electro thermal heater or hot plate. The distillation flask was attached a Liebig condenser connected to a receiver beaker containing $10 \mathrm{ml}$ of $2 \%$ boric indicator (Boric acid and universal indicator mixed together). Sodium hydroxide was injected into the digest via a syringe attached to the mono-arm steelhead until the digest became strongly alkaline. The mixture was heated to boiling and the distilled ammonia gas via the condenser into the receiver beaker. The color of the boric acid changed from purple to greenish as ammonia distillate was introduced into the boric acid.

The distillate was titrated with standard $0.1 \mathrm{~N}$ hydrochloric acid solutions back to purple from greenish. The volume of hydrochloric acid added to effect this change was recorded as titre value.

\section{Carbohydrate Content Determination}

$0.1 \mathrm{~g}$ of the sample was weighed into a $25 \mathrm{ml}$ volumetric flask, $1 \mathrm{ml}$ distilled water and $1.3 \mathrm{ml}$ of $62 \%$ perchloric acid was added and shaking for a period of 20 minutes to homogenize completely. The flask was made up to 25 $\mathrm{ml}$ mark with distilled water and stopper. The solution formed was filtered through a glass filter paper or allowed to sediment and decanted. $1 \mathrm{ml}$ of the filtrate was collected and transferred into a $10 \mathrm{ml}$ test tube this was diluted to volume with distilled water. $1 \mathrm{ml}$ of working solution was pipette into a clean and $5 \mathrm{ml}$ anthrone reagent was added, $1 \mathrm{ml}$ distilled water and 5 $\mathrm{ml}$ anthrone reagent was mixed similarly and the whole mixture were read at $630 \mathrm{~nm}$ wave length using the $1 \mathrm{ml}$ distilled water and $5 \mathrm{ml}$ anthrone reagent prepared as blank to zero the machine. Solution glucose was also prepared and was treated as the sample with anthrone reagent. Absorbance of the standard glucose was read and the value of the carbohydrate as glucose was calculated.

\section{Moisture Content Determination}

A homologous quantity of the fresh sample was taken and weighed in a weighing balance and the weight recorded and sample was placed in a porcelain evaporating dish. This was place in an oven for duration of $24-48 \mathrm{~h}$. The evaporating dish was cooled in a desiccator to room temperature and then re-weighed and recorded. The percentage moisture of the sample was calculated.

\section{Lipid Content Determination}

$10 \mathrm{~g}$ of grinded sample was inserted into a filter paper (thimble) and was place into a soxhlet extractor. The extractor was placed into a pre-weighed dried distillation flask. Then acetone was introduced as an extracting agent into the distillation flask via the condenser end attached to the soxhlet extractor. The set up was held in place with a retort stand clamp on the hot plate. Cooled water jet was allowed to flow into the condenser and the heated solvent was refluxed as a result. The lipid in the solvent was extracted in the process of continuous refluxing. When the lipid was observably extracted completely from the sample under test, the condenser and the extractor was disconnected and the solvent was evaporated to concentrate the lipid. The flask was then dried in the air oven to constant weight and reweighed to obtain the weight lipid.

\section{Ash Content Determination}

1 gram of the sample was weighed into porcelain crucible which was previously preheated and weighed. The crucible was inserted into a muffle furnace and regulated to a temperature of $630{ }^{\circ} \mathrm{C}$ for three $\mathrm{h}$ and allowed to cool to room temperature, and then reweighed.

\section{RESULTS AND DISCUSSION}

The phytochemical analysis of Ipomoea cairica (Fig. 1.1) shows that phytate composition was recorded to be the lowest and alkaloid the highest. Cyanogenic glycoside concentration was quite low which shows that Ipomoea cairica is good for consumption (not poisonous), and contains good proportion of other food supplements. There where high values of alkaloids and Saponins. Alkaloids have been shown to possess antimicrobial activity and therefore have been helpful in inhibiting pathogenic organisms. This makes them very useful in the pharmaceutical industries in the treatment of ailments (Panaccione, 2005). Similarly, the application of saponin is very diverse. Studies have shown that saponins have antitumor and anti-mutagenic activities and can lower the risk of human cancers, by preventing cancer cells from growing. Saponins seem to react with the cholesterol rich membranes of cancer cells, thereby limiting their growth and viability. Saponin can also be used in the production of detergents and related products. When mixed with water, it reduces the surface tension of water, allowing the formation of small stable bubbles. As a consequence of their surface-active properties, saponins are excellent foaming agents (very stable). Today, saponins are used in the manufacture of foam extinguishers, toothpaste, shampoos, liquid soaps, and cosmetics and to increase the foaming qualities of beer and soft drinks. Saponins come in powdered or liquid form and can be found in fertilizers (amendments) and soilless potting mixes and certain pesticides (insecticides), kitty litter, detergents, beverages, lipsticks, herbal skin balms, and many other things 
(Ferreira et al., 2006). The presence of saponin alone in Ipomoea cairica tuber makes it very useful in wide range of fields.

The flavonoid content of the plant was also relatively high. This indicates that Ipomoea tuber can be used as food additive. Like saponins and alkaloids, flavonoids also possess many pharmacological activities like anti- ulcer, anti-ageing, anti-bacterial, anti-oxidant, antifungal, anti-inflammatory, anti-diabetic, anti -hepatotoxic, anti-allergic, anti-cancer, anti-tumor and vasodilator properties (Shohaib et al., 2011), hence can be applied in the field of medicine when extracted from Ipomea cairica.

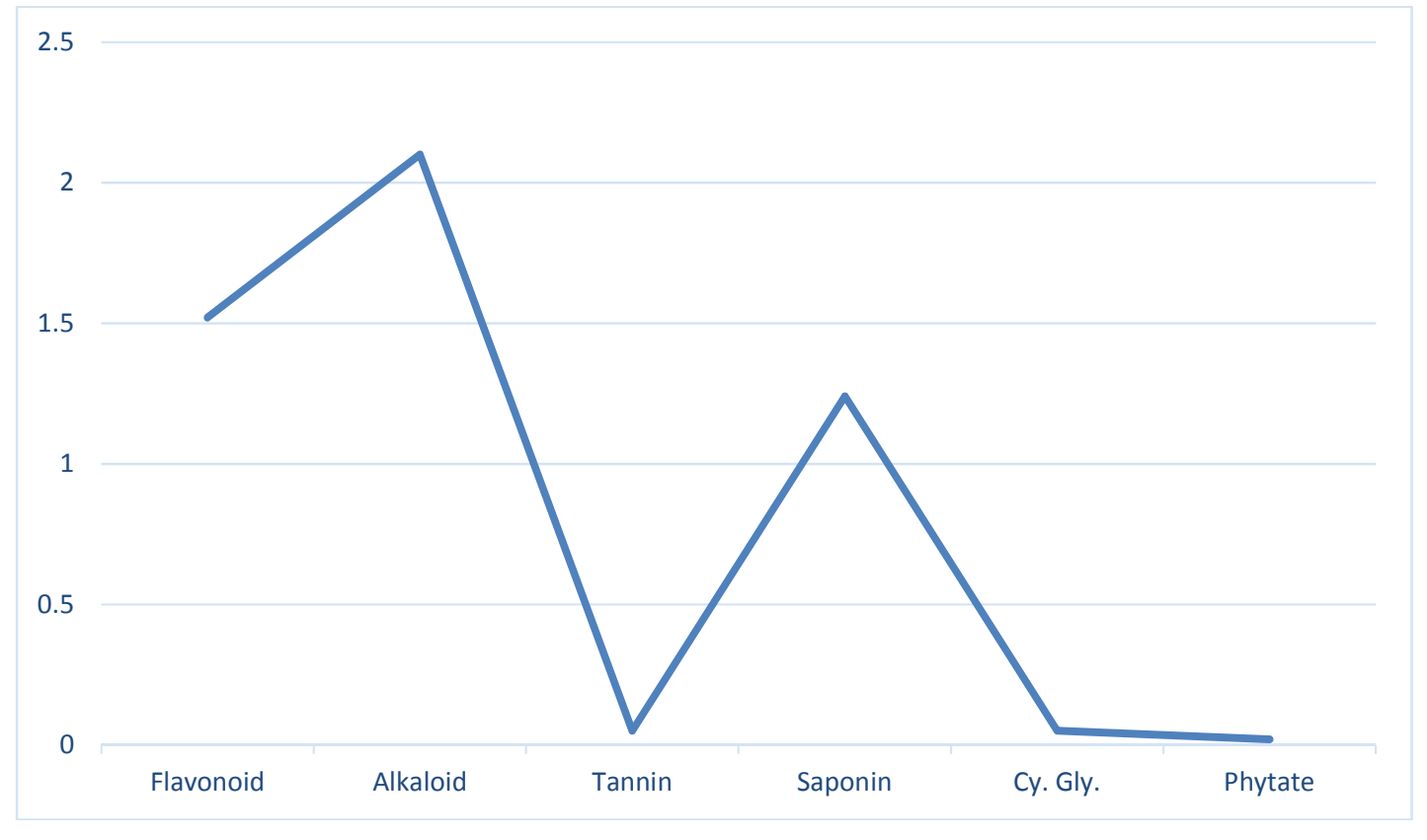

Fig. 1.1 Showing phytochemical analysis of Ipomoea cairica tuber

The results in Fig. 1.2 shows that the tuber's moisture content was highest $(72.7 \pm 0.2 \%)$, with lipid having the lowest, $0.51 \pm 0.07 \%$. From the results of the proximate analysis, the carbohydrate content was shown to be about $12 \%$. This indicates that Ipomoea cairica is a source of energy since carbohydrate provides energy for all body functions and muscular exertion; it also assists in the digestion and assimilation of other foods. Protein which was present at a significant level (4.2\%) is equally an essential requirement of the body. Protein is one of the basic building blocks of the human body, making up about $16 \%$ of our total body weight (Dewick, 2002). Muscle, hair, skin, and connective tissue are mainly made up of proteins. However, protein plays a major role in all of the cells and most of the fluids in our bodies. In addition, many of our bodies' important chemicals, enzymes, hormones, neurotransmitters, and even our DNA are at least partially made up of proteins (Dewick, 2002). Ipomea cairica therefore, can be used as food source to provide energy to the body, repair and maintain tissues

The Ash and Lipid content of Ipomoea cairica tuber were relatively low. They were shown to be $0.6 \pm 0.1$ and $0.51 \pm 0.07 \%$, respectively.

The high value of moisture indicates that Ipomoea cairica tuber has a high water content. Fruits and vegetables contain large quantities of water in proportion to their weight. When these foods are eaten, the water can be absorbed and used by the body (Sharda, 1999). 


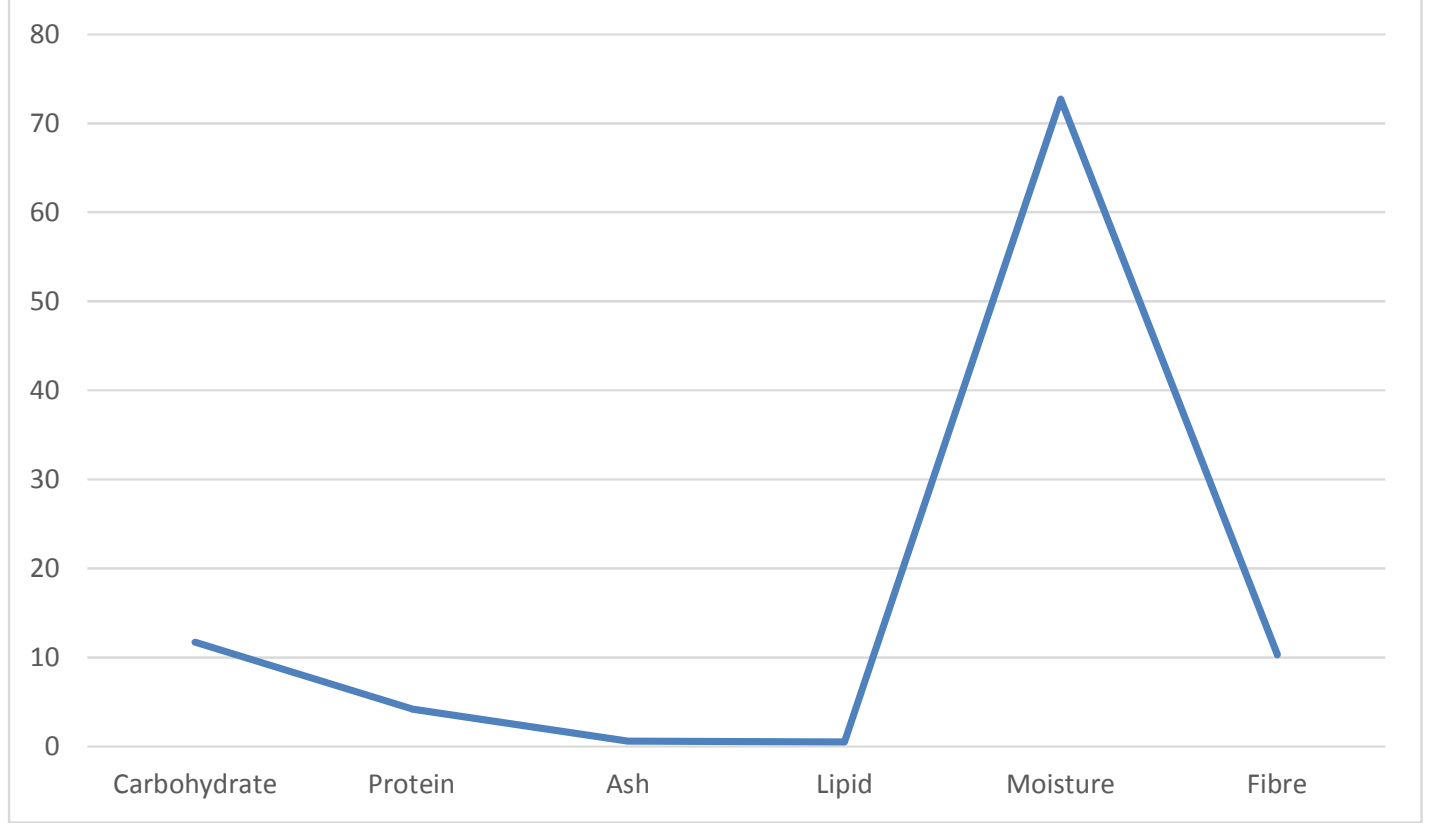

Fig.1.2 Showing Proximate composition of Ipomoea cairica tuber

\section{CONCLUSION}

These analyses revealed the importance of Ipomoea cairica in diverse ways. The findings of this work therefore suggests that Ipomea cairica will be useful as an antimicrobial agent as well as for food owing to its proximate composition. The phytochemical analysis of Ipomoea cairica showed high content of alkaloids, saponins and flavonoids. The presence of alkaloids makes it possible for use in dye production, spices, drugs and anti-fungals. The proximate analysis of Ipomoea cairica showed high presence of carbohydrates, proteins and fibres all of which are necessary nutrient for growth and development of the body. The tuber of Ipomoea cairica can be used as a substitute for other mostly consumed tuber foods like yam and cocoyam.

Based on these observations, Ipomoea cairica having been isolated, purified and tested provides possible therapeutic, economic and food advantage.

\section{REFERENCES}

Abou-Chaar C. I., 1997. "Alkaloids of an Ipomoea seed", Lebanese Pharm. J. 9, 93-109.

AOAC (Association of Official Analytical Chemists) International 2005. Official Methods of Analysis of AOAC International; $18^{\text {th }}$ ed. Gauthersburg Maryland USA, AOAC international.

Austin D. F. and Z. Huaman, 1996. "A Synopsis of Ipomoea (Convolvulaceae) in the Americas". Taxon, 45, 3-38.
Barker, B., R. Barker, J. Jessop, and H. Vonow, 2005. "Census of South Australian Vascular Plants". $5^{\text {th }}$ ed. The Botanic Gardens of Adelaide and State Herbarium, Government of South Australia, Adelaide, South Australia. http://www.wikipedia.org. Ipomoea cairica. Accessed March, 2014.

Brisbane City Council, 2007. "Morning Glory and Mile-aMinute (Ipomoea cairica and Ipomoea indica). Wipe out weeds". www.brisbane.qld.gov.au. Accessed May, 2015.

Cao S, R. C. Guzza, J. H. Wisse, J. S. Miller, R. Evans and D. G. Kingston, 2005. "Ipomoeassins A-E, Cytotoxic Macrocyclic Glicoresins from the Leaves of Ipomoea Squamosa from the Suriname rainforest". J, Nat. Prod., 68, 487492.

Dewick P. M., 2002. "Medicinal Natural Products. A Byosynthetic Approach". 2. ed. New York: John Wiley and Sons Ltd. 206-215

Ferreira A. A. F. A. Amaral, I. D. Duarte, P. M. Oliveira, R. B. Alves, D. Silveira, A. O. Azevedo, D. S. Raslan and M.S. Castro, 2006. "Antinociceptive Effect from Ipomoea cairica extract". J. Ethnopharmacol105, 148-153.

Panaccione D. G., 2005. "Origins and Significance of Ergot Alkaloid Diversity in Fungi. FEMS". Microbiol Lett. 251, 9-17. 
Pereda-Miranda R. and M. Bah, 2003. "Biodynamic Constituents in the Mexican Morning Glories: Purgative Remedies Transcending Boundaries". Curr. Top Med. Chem., 3, 111-131.

Sharda S. and C. K. Kokate, 1999. "Indole Alkaloids from the Leaves of Ipomoea Palmata Forsk". Indian Drugs 17, 70-71.

Shohaib.T, M. Shafique, N. Dhany and C. D. Madhu., 2011. "Importance of Flavonoides in Therapeutics". Hygeia. J. D. Med. 3 (1), 1-18
Stefanovi S., D. F. Austin and R. G. Olmstead, 2003. "Classfication of Convolvulaceae: A Phylogenetic Approach”. Syst. Bot. 28,791-806.

Teow C. C., V. D. Truong, R. F. Mc Feeters, R. L. Thompson, K. V. Pecota and G. C. Yencho, 2007. Food Chemistry, 103; 829.

Wagner H., 1993. The Chemistry of the Resin Glycosides of the Convolvulaceae family, in: Bendz G, Santesson J. (eds.), Medicine and Natural Sciences, Chemistry in Botanical Classification, Academic Press., New York, 235-240. 